\title{
THE HISTORY OF MILITARY TOXICOLOGY
}

\author{
Jiři Bajgar, Josef Fusek
}

Military Medical Academy, Hradec Králové; (Rector: doc. MUDr. S. Býma, CSc.)
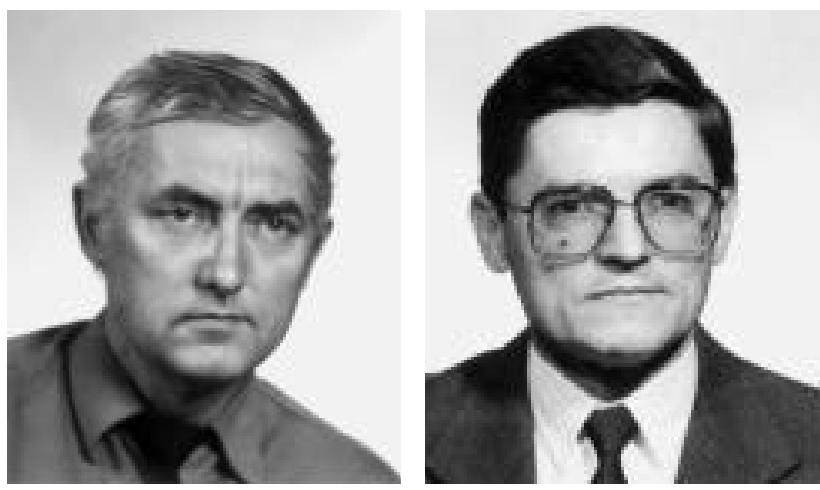

COL Assoc. Prof. J. Bajgar, (1944) COL Prof. J. Fusek (1945)

Research on protection against CWA was very intense in the former Czechoslovakia. As early as pre-WW II, this research was conducted at the Military Technical Institute in Prague. In the fifties, the medical and technical topics were separated and the medical aspects were delegated to the Department of Toxicology (DTOX), Military Medical Academy (MMA), Hradec Králové. Military toxicology is a prime responsibility of the DTOX. The MMA was founded in 1951 and the DTOX, without experience or equipment, began its work on 1 September 1951 in one room of the civilian Medical Faculty of Charles University. Its total equipment on hand was one typewriter and two masks.

All the activities were focused to education, however, research work begun. Technical equipment was enlarged, e.g. Lange's photometer, oscilometer, Warburg instrument. The first head of the Department was Prof. MUDr. Zdeněk Fink, DrSc..

In the sixties initial scientific work focused on research into the mode of action of mustard gas, cyanide and nerve agents. The results of this research were classified secret and had little or no publicity and practically no outlet into scientific journals. One result of this research was the development and production of pralidoxime (PAM Spofa) which was introduced into the Armed Forces. In 1965, the lay syringe (LIS) for self-administration of atropine was introduced into the Czechoslovak Army. This particular research effort during the sixties and later into the seventies, resulted in the assessment of the maximal available doses of nerve agents for man.

By the end of the sixties and the Prague Spring, the first publications of the DTOX were seen in scientific literature.
However, the name of the Department as well as the term „military“ were excluded from the title. The Institute was designated as the Medical Research Institute for foreign journals only. On the other hand, in the Czech journals which were freely circulated abroad, the word „military“ was present as well as other specifications such as military rank.

At this time, the Department was equipped with techniques on very sophisticated basis, e.g. fluorimeter Farrand, Auto Analyzer Technicon, ultracentrifuge MSE etc. The staff of the Department was also on high level able to cover the research of toxic substances from synthesis and analysis (Ing. F. Ornst, CSc.) later on through toxicity testing (MUDr. M. Krejcar, CSc.; MUDr. V. Hrdina, CSc.), including percutaneous route of administration (MUDr. V. Vondráček, CSc.), biochemical characterization in vitro and in vivo (MUDr. Tulach, CSc. and MUDr. A. Jakl, CSc.), histochemical evoluation (MUDr. R. Urban, CSc.) and development of antidotal treatment (Dr. J. Vachek). In the year 1968, Prof. Fink was named the Head of the whole institute (Purkyně Military Medical Research and Postgraduate Institute). New chief of the DTOX was Doc. MUDr. V. Vondráček, CSc. Prof. Fink was in this post till 1971. Then he had to leave the Army as a result of a political persecution during the so called ,period of normalization" which started after the year 1969.

Although the political situation changed substantially after the Prague Spring, all activities of the DTOX more or less continued. During the seventies to eighties, COL. Prof. Ing. Jiři Matoušek, DrSc. was a new member of the DTOX staff. His work focused on development of new decontamination agents that resulted in a decontamination kit based on sorption mechanical principle (DESPRACH) for the Czechoslavak Army and Civil Defence. In the year of 1973, COL Prof. MUDr. V. Hrdina, CSc. was named the Head of the Department.

Education at the MMA, which was focused on military toxicology, began to consider more modern techniques of video, movies, computers, etc. More than 10 movies were produced at the DTOX. These dealt with, amongst other subjects, clinical laboratory diagnosis of organophosphate and other chemicals poisoning.

Some research works on intoxication with psychotomimetic compound, e.g., LSD-25, IDPN and BZ and their treatment were done and prospective antidotes were studied in a more detailed fashion. New concrete antidotes against 
nerve agents (FOSAN, CHONOL I and II, RENOL) prophylactic antidote against organophosphates (PANPAL) and antidote (7-MEOTA) against psychotomimetic compound $\mathrm{BZ}$ were real results of this research which were finalized by the end of the eighties.

Modernization also was also seen in the means of administration; the autoinjector GAI containing atropine and obidoxime was developed for the Army in cooperation with the former GDR. After the so-called „velvet revolution“, a new head of the DTOX was elected (COL doc. MUDr. J. Bajgar, DrSc.), and research dealing with further study of action of CWA and their antidotes was continuing in two research projects designated as OTRAL and SOMAN.

OTRAL described the toxic effect of the new nerve agent $\mathrm{GV}$, with properties similar to $\mathrm{G}$, as well as V. compounds, and GV's medical treatment by the usual antidotes, which is difficult. Cholinesterase activity in the blood following GV and other nerve agents (soman, sarin, VX) intoxication, corresponded to activity in the target organs and enabled us to assess the degree of inhibition corresponding to different symptoms.

Some aziridine neurotoxins were characterized using electrophysiological and behavioral methods including the method for testing of non-lethal effect (spontaneous motor activity). The suitability and sensitivity of the method was demonstrated using various derivatives of aziridines, nerve agents, mustard and BZ.

Further details on the action of antidote (7-MEOTA) against BZ intoxication, expecially different inhibitions of molecular forms of rat brain acetylcholinesterase (AChE) by 7-MEOTA and good tolerance following administration to healthy volunteers were reported.

SOMAN: Inhibition of AChE in the rabbit red blood (RBC) cells to zero activity by soman was described. A reinfusion of these erythrocytes to normal rabbits, with a corresponding decrease of up to $60 \%$ of controls (caused by mixing with normal RBC) was demonstrated in these animals. All animals survived $24 \mathrm{~h}$ following transfusion.

An increase of DNA content in the liver was also demonstrated following from $1 \mathrm{~h}$ to 3 days of soman administration. Synthesis and physico chemical properties of the ester and amide of 4-substituted 2-pyridinealdoxime and tetroxime were characterized. Their biological effects were compared with those of HI-6.

All compounds suppressed cholinergic and noncholinergic changes following soman poisoning, however, superiority of HI- 6 and its ability to reactivate inhibited AChE in the brain was observed. The best prophylactic, 5 hours lasting effect was PANPAL (combination of pyridostigmine, benactyzine and trihexyphenidyle). The prophylactic effect was demonstrated when administered 2 hours before soman intoxication. Moreover, the subsequent antidotal treatment with HI-6 and benactyzine potentiated the prophylactic effect of PANPAL.

The last part described reaction of cyclodextrines (as potential decontaminants) with soman. A list of all publiactions is available.
After an accident in which Prof. Bajgar fractured two vertebra, COL Prof. MUDr. J. Fusek, DrSc. became the new head of DTOX and also the rector of the whole Academy. Other officers of the staff of the DTOX include: LTC MUDr. O. Krs, CSc. (histology); LTC doc. MUDr. J. Kassa, CSc. (biochemistry) and LTC Ing. J. Cabal, CSc. (decontamination). There are also very qualified and experienced civilian research professionals participating in research in the following areas: Dr. J. Vachek (antidotal treatment and development of antidotes); doc. RNDr. J. Patočka, DrSc. (enzymology); MUDr. J. Herink, DrSc. (electroencephalography); RNDr. M. Koupilová, CSc. (behavioral techniques) and Ing. J. Bielavský (synthesis of chemicals). Their contributions are of great importance for the final results in the many and varied areas.

There was also another research direction: in the sixties there were some rumors in the press concerning testing and weaponization of psychotomimetic agents in some NATO countries. As a reaction to this information, the Czechoslovak Army proposed a testing of potential psychotomimetic agents which might be identified for military use and experimental work was begun.

LSD-25 was tested as the first compound. Some changes in the content of catecholamines, acetylcholine and cholinesterase activity in the brain were observed, including the influence of LSD-25 on behaviour in laboratory rats and in some cases dogs. The effect of LSD-25 was tested on two groups of officer volunteers simulating the work of a commander and his staff during military operations. Members of the staff with LSD-25 administration were unable to work after 30-45 minutes following administration (60 $\mu \mathrm{g} /$ person, p.o.), and this lasted for a 3-6 hour period.

However, according to data in the literature, as well as an increasing amount of baseline data we were establishing, it was becoming clear that LSD-25 could represent a model for study of psychotomimetic effect rather than chemical warfare agent; a weaponized compound would not be LSD.

Therefore attention was focused on the group of anticholinergic as well as psychotomimetic effects. From this group of compounds, JB-336, Ditran, BZ and others were studied. Later on, BZ was found to be the most important and it was studied in detail. According to a character of this compound, physostigmine as a military antidote was first proposed. However, its side effects and relatively high toxicity were stimulating the drive to search for a new drug, preferably with reversible cholinesterase inhibitors.

Because of the known effects of Tacrin as a representative of this group, some other acridine derivatives were synthesized and characterized with the intent to find a substance less toxic than Tacrin.

Hundreds of compounds were synthesized and anticholinesterase activity was tested and tens of them were characterized toxicologically. The 7-methoxy derivative (7-MEOTA) of Tacrin was found to be the most effective against BZ intoxication. Moreover, its toxicity expressed as LD50 (rat, $258 \mathrm{mg} / \mathrm{kg}$, i.m.) is lower than the toxicity of Tacrin (rat, $33.8 \mathrm{mg} / \mathrm{kg}$, i.m.). Therefore it was decided on 
the use of this drug as an antidote against BZ intoxication in the Czechoslovak Army. Shortened toxicity tests for single use of 7-MEOTA were performed at the DTOX of the Military Medical Academy (Hradec Králové) and the Army was equipped 7-MEOTA as an antidote against BZ (100mg tablets) in 1991.

Other experiment dealing with further study of the mechanism of 7- MEOTA were done. The results achieved demonstrated that this durg would be useful in the treatment of other conditions than just intoxication with BZ, e.g. tardive dyskinesias, Alzheimer's disease, prolongation of anaesthesia etc. For multiple chemical use of the medicament, a chronic toxicity study (1 year) was done at the Research Institute of Pharmacy and Biochemistry, VÚFB Rosice nad Labem, but it was not evaluated until the end of 1996. However, it was decided by the Ministry of Defence at the same time that the problem of treatment of civilian diseases is not in the scope of the Army and funding was stopped.

Approximately at the same time, the USA declared that all of their stocks of BZ were destroyed (CD/1074, 1991). The Czech Army now had an antidote against a non existing chemical warfare agent. This story was described and documented at the first Chemical and Biological Medical Treatment Symposium in Spiez, Switzerland in December 1994 by Professors Fusek and Bajgar (Antidote Against BZ Intoxication: a Story of 7-MEOTA).

More detailed data on this subject are given in the textbook of the Czech Military Medical Academy „History of the use of chemical weapons and negotiations on their prohibition" published by the MMA, Hradec Králové, textbook No 302, 1996.

Following velvet revolution in 1989 , the new possibilities for further contacts over the world were opened. The Department was very active at the Organization for Prohibition of Chemical Weapons (The Hague): on the Task Force on Medical Treatment, the Department tabled 8 working papers. Dr. Bajgar was invited by the same organization to teach international inspectors for Convention on prohibition of chemical weapons (entered into force on 29 April 1997). He is also a member of Scientific Advisory Board on the Applied and Sciencies Analysis (USA). Department of Toxicology has been awarded (NATO Scientific Committee) by Linkage Grant dedicated to solve the problem of treatment of nerve agent poisoning, in cooperation with Military Medical Academy in München. The research results of the Department were published in more then 140 publications and cited more than 200 times (1993 - 1996) according to Institute for Scientific Information (USA). The members of the Department presented their results also in different scientific meetings, symposia and conferences, in some cases as chairs of sessions or invited speakers, e.g. 1st and 2nd C-Schutz Tagen, München, 1995 and 1997 (Fusek, Bajgar, Krs), 5th North American Congress of Clinical Toxicology Rochester, 1995 (Bajgar), 12th International Conference on Alzheimer Disease, Jerusalem, 1996 (Fusek), Workshop IITRI Chicago 1996, 1997 (Bajgar) etc.
From the results achieved, it can be mentioned following:

- synthesis of tetrahydroaminoacridine derivatives (hundreds). 7-Methoxyderivative - 7-MEOTA was chosen as the best for clinical and antidotal use. Development of tablets and injections was finished and the drug was tested on volunteers.

- synthesis of four medicaments for the treatment of nerve agents poisoning and four compounds for testing of neurotoxicity

- finalizing of development of mentioned antidotes such CHONOL I and II, FOSAN, RENOL, PANPAL and 7MEOTA.

- synthesis of new reactivator HI-6, elaboration of method for its production and $1.5 \mathrm{~kg}$ of HI- 6 was produced for the Czech Army.

- analytical determination of nerve agents was improved

- diagnosis of nerve agent poisoning was improved to achieve better sensitivity

- the method for neurotoxicity testing was developed

- new group of nerve agents (GV) was characterized

- the results were published in the Czech and foreign Journals

- in the period 1989-96, 6 textbooks were elaborated.

- 5 authorized attestations and 2 patents were obtained

- for education, two cinemas and nine movies were produced

\section{List of the Heads of the DTOX:}

COL prof. MUDr. Zdeněk Fink, DrSc.

Born 29 May 1919, died 15 September 1995. Head of the DTOX 1952-1968. Pharmacology of acetylcholine, study of its level following effects of some toxic compounds. Solving of vital functions during intoxication with psychtomimetic agents. Effect of parasympatholytics on isolated organs. One of the founders of military toxicology.

COL doc. MUDr. Vladislav Vondráček, CSc.

Born 26 December 1921, died 4 June 1973. Head of the DTOX 1968-1973. Study of effects of mustard and possibilities of its decontamination. Maximally permitted doses of nerve agents. Precise methodical approach.

\section{COL prof. MUDr. Vratislav Hrdina, CSc.}

Born 11 April 1926. Head of the DTOX 1973-1989. Study of catecholamine levels following intoxication with nerve agents and antidotal treatment. Study of delayed neurotoxicity.

\section{COL doc. MUDr. Jiří Bajgar, DrSc.}

Born 18 january 1944. Head of the DTOX 1989-1993. Study of effects of inhibitors and other factors on cholinesterases including their multiple molecular forms. Inhibition and reactivation of these enzymes in vitro and in vivo. Transfer of data from animal to man. Development of antidotes against nerve agents. 
COL prof. MUDr. Josef Fusek, DrSc.

Born 12 May 1945. Head of the DTOX 1993-now. Study of effects of toxic compounds and drugs on isolated organs. Monitoring of physiological functions following intoxications and treatment. Solving the problems of psychotomimetic compounds and development of specific antidote 7-MEOTA.

$\mathrm{x}$ Scientific degrees are introduced in Czech equivalents

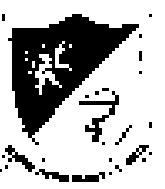

Doc. MUDr. Jiří Bajgar, DrSc.,

Military Medical Academy, 50001 Hradec Králové,

Czech Republic. 